\title{
Analysis of Nigerian Electricity Generation Multi Year Tariff Order Pricing Model
}

\author{
Nnamdi B. Anosike1 ${ }^{*}$, Jude E. Dara1, Ugochukwu C. Ngwaka², Frances O. Enemuoh ${ }^{3}$ \\ ${ }^{1}$ Mechanical Engineering Department, Nnamdi Azikiwe University, Awka, Nigeria \\ ${ }^{2}$ Mechanical Engineering Department, Enugu State University of Science and Technology, Enugu, Nigeria \\ ${ }^{3}$ Electrical Engineering Department, Nnamdi Azikiwe University, Awka, Nigeria \\ Email: ^nb.anosike@unizik.edu.ng
}

How to cite this paper: Anosike, N.B., Dara, J.E., Ngwaka, U.C. and Enemuoh, F.O. (2017) Analysis of Nigerian Electricity Generation Multi Year Tariff Order Pricing Model. Energy and Power Engineering, 9, 541-554.

https://doi.org/10.4236/epe.2017.910038

Received: July 20, 2017

Accepted: September 8, 2017

Published: September 11, 2017

Copyright $\odot 2017$ by authors and Scientific Research Publishing Inc. This work is licensed under the Creative Commons Attribution International License (CC BY 4.0).

http://creativecommons.org/licenses/by/4.0/ (c) (i) Open Access

\begin{abstract}
The Multi Year Tariff Order (MYTO) is the Nigerian Electricity Regulatory Commission (NERC) pricing framework for determining the Nigerian Electricity Supply Industry (NESI) pricing model. One of the objectives of the NERC's MYTO pricing model is to ensure regulated electricity end user tariff without compromising return on investment. Achieving this objective is imperative to attract investors in the growing Nigerian electricity market. However, NESI has hitherto been faced with challenges ranging from its inability to provide sufficient power to its customers to not being viable enough to provide return on capital invested. In this paper, sensitivity analysis of power plant operation and performance parameters on the cost of electricity (CoE) generation using MYTO (power generation) pricing model were evaluated. Thermodynamic modeling and simulation of an open cycle gas turbine (OCGT) was carried out to augment scarce data on power plant performance and operation in Nigeria. Sensitivity analysis was carried out using probabilistic method based on Monte Carlo simulation (MCS) implemented in commercial software (@ Risk ${ }^{\circledR}$ ). The result highlighted sensitivity of the model input parameters to cost of electricity generation based on technical and financial assumptions of MYTO model. Seven most influential parameters affecting generation cost were identified. These parameters and their correlation coefficients are given as: 1) foreign exchange rate, $0.76 ; 2$ ) cost of fuel, $0.51 ; 3$ ) thermal efficiency, -0.23 ; 4) variable operation and maintenance cost, 0.22 ; 5) fixed operating and maintenance cost, -0.03 ; 6) capacity factor, -0.02 ; and 7) average capacity degradation, 0.01 . Based on the gas turbine engine and input parameter distributions statistics for this study, the generation cost lies between 9.84 to $15.45 \mathrm{~N} / \mathrm{kWh}$ and the probabilities of $\mathrm{CoE}$ within these values were established.
\end{abstract}




\section{Keywords}

Nigerian electricity Market, Generation Multi Year Tariff Order (MYTO), Combustion Turbine, Electricity Price Uncertainty,

Government Interventions

\section{Introduction}

Proper energy mix with adequate production is a target of every nation in achieving her energy demands and meeting stringent emission requirement. One of the major reasons Nigeria is less attracted to start a new business or expansion of existing business is unacceptable blackouts in national grid which impact customers, particularly commercial and industrial users; almost causing them to go entirely off grid [1]. The analysis of Nigeria's electricity supply problems and prospects found that the electricity demand in Nigeria far outstrips the supply, which is epileptic in nature [2]. The erratic electricity supply hinders the country's development, restricts socio-economic activities to basic human needs and adversely affects the quality of life [3] [4].

Nigeria with low energy generation capacity and inadequate energy generation mix alike is facing multi-dimensional challenges in meeting her energy requirement of at least 10,000 MW. Hence, the Nigeria government in a bid to reposition the electric sector in 2005 came up with Electric Power Sector Reform Act (EPSRA, 2005) to boost energy generation and distribution capacities in the country. This leads to privatization of two segments of its electricity industry; generation and distribution sectors, anticipating that investors can take over and produce sufficient power to meet growing electricity needs of Nigerians. The transmission segment is still under monopoly (controlled by the government); while retail is coordinated within the distribution companies (Discos). Though the transmission and distribution infrastructures are insufficient to evacuate the proposed 10,000 MW and require attention. However, generation remains the most challenging presently. Transmission problems can be somewhat taken care of upon introduction and increased number of distributed or embedded power generation. The NESI is majorly characterized by centralized power plants, which feed into the national grid and the power is then apportioned to different distribution companies through the Nigerian bulk electricity trading (NBET) company. The current long distance transmission lines leads to technical losses, increased externalities and poor voltage profile which results to higher final tariff payable by the end user. Ensuring improved efficiency, access and reliability of the energy industry as well as establishing a competitive market in the country, requires investors in the core areas, especially in the generation segment of the industry. Thus, a visible and consistent polices to guarantee capital recovery, returns on investment for investors while maintaining affordability and quality of service to consumers must be in place [5]. 
The Section 76 (6) of the EPSRA Act, 2005 empowers Nigerian Electricity Regulatory Commission (NERC) to establish tariff methodologies for regulating electricity prices in Nigeria. NERC in 2008 introduced a pricing model, the so called "Multi Year Tariff Order (MYTO)" as the framework for determining the Nigerian Electricity Supply Industry (NESI) pricing structure. Close to a decade of the MYTO model introduction, the NESI has hitherto been faced with numerous challenges ranging from its inability to provide sufficient power to its customers to not being viable enough to provide return on capital invested. According to Iwayemi, 2008 [6], NESI is probably one of the most inefficient in meeting the needs of its customers globally.

The MYTO review is a critical step towards electricity sector viability and immediate growth [7]. Fundamentally, the assumption that available electricity assets are used to their maximum capacity as embedded in MYTO [8] can be somewhat detrimental to cost of electricity ( $\mathrm{CoE})$ generation from operators perspective. For instance, effect of highly influential ambient temperatures on gas turbine performance is not considered; acute part-load operations due to several reasons which in most cases are beyond operators' control were not envisaged. These unprecedented changes in plant operations attract performance penalties to include reduction in thermal efficiency, availability and capacity factor. Such penalties directly affect most economic appraisal parameters like the net present value (NPV), internal rate of return (IRR), payback period (PBP) and so on. In most cases gas turbine units in some plants are unavoidably redundant because of problems beyond operators' control. This could be a deterrent for prospective investors and reduce the anticipated growth of the electricity industry. This could be the case until such times when NERC deem market to be matured enough to implement optimized and realistic pricing model.

Typically, techno-economic models like MYTO developed under several influences ranging from lack of stability of macroeconomic assumptions; unstable marketing performance; underutilization of available power plant technology; and volatile government policies will be prone to uncertainties with issue of risk allocation. Thus, the economic and technical performance of power plant in this situation carries several uncertainties arising from number of sources Sensitivity study is important for accessing the robustness and appraisal's conclusion [9] [10]. The probability distribution is much more realistic way of describing uncertainties in variables for risk analysis [11]. Probabilistic approach differs from the conventional deterministic approach in the sense that it accepts model input inform of distribution and with Monte Carlo simulation (MCS) produce model output as probability distribution function (PDF). In addition probability approach provides useful information in doing "What if scenario" analyses. The probability distribution of the model input variables can be constructed from historic data or forecast model. Electricity forecast model is divided into two major categories: top-down and bottom-up [12]. The top-down forecast approach uses huge historical data and the most forecasting methods such as regression, time series, fuzzy logic, neural network, and expert system belong to 
top-down forecast approach [13] [14] [15]. On the other hand, the bottom-up approach involves developing engineering modules and using it to capture data at appliance level [16] [17]. The dependency of top-down forecast approach on past data means it does not detect incremental changes that may occur slowly but radical in forecasting behavioral changes.

The suboptimal performance described as nonviable enough to provide return on capital invested in Nigerian electricity generating (Gencos) sector as part of challenges facing NESI is evaluated in this paper. The sensitivity analysis of the so called "Nigerian Electricity Generation Charges Multi-Year Tariff Order" financial model is evaluated against typical natural gas fired combustion turbine (CT) or open cycle gas turbine (OCGT) performance. This was done considering the performance parameters envisaged to be affected with the operational condition of the power plant experienced in Nigeria today.

\section{Description of Multi-Year Tariff Order (MYTO) Methodology}

There are three MYTOs; one for each of the sectors in the NESI namely: generation, transmission and distribution/retail. In preparing the MYTO pricing model, NERC had proclaimed the basic targets were: fairness; lowest possible regulated end user tariff without compromising return on investment; simple, transparent and non-excessive regulatory costs. The commission used the building block approach in determining the regulated prices for transmission, distribution and retail tariff path. The building blocks approach is based on projection of performance, believed to have a combined positive attribute of rate of return regulation and price caps. However the methodology for generation is different and employs the long run marginal cost (LRMC) method. The three standard building blocks used in the MYTO development as narrated by Ransome Owen [8] were to achieve the following: allowing return on capital-being the return necessary to achieve a fair rate of return on the necessary assets in the business; allowing return of capital-associated with recouping the capital over the useful lives of the assets (depreciation); and finally efficient operating costs and overheads.

The MYTO model is subject to short term minor and long term major reviews. The model since its creation in 2008 (MYTO-1) had seen two major reviews in 2012 (MYTO-2) and 2015 (MYTO-2015). However, the generation tariff order did not see a major change in the MYTO 2015. The current major review for MYTO-2015 tariffs is based on a ten (10) year tariff path (2015-2024). Section 7 of the MYTO-2 mandates the commission to carry out bi-annual minor review for generation, transmission and distribution tariffs. This stated clearly the four parameters to be considered in the review as: foreign exchange rates, gas prices, rate of inflation and generation capacity. Price variation of plus or minus five percent $( \pm 5 \%)$ in any of these parameters will lead to the model review. whilst the MYTO major reviews is said to encompass a comprehensive review and overhaul of the overall assumptions in the model. However, this paper is concerned 
with the generation tariff order or generation charges multi-year tariff order. This is the regulated prices to be paid to licensed electricity generation companies (Gencos) in providing electricity to distribution and retailing companies (Discos). The generation tariff order is divided into two parts; one representing the proclamation of the order and other representing the basis of the other. The detailed information of this generation tariff order is presented in NERC document NERC/GL115 [18].

Based on cheap price of natural gas in Nigeria, NERC determined that the lowest-cost for new entrant generator will be an open-cycle gas turbine (OCGT) using natural gas. Cost of electricity (CoE) from this technology according to NERC is lower than combined-cycle gas turbines (CCGT) and coal-fired generation. This trend is predicted to change in near future as gas price becomes market-based; then CCGT is likely to emerge as the benchmark for a lowest-cost new entrant generator. Following the establishment of the OCGT or combustion turbine (CGT) as the new-entrant generator, benchmark for MTYO generation tariff was developed upon this technology for gas fired power plant. The initial method adopted here was to allow the NESI move to a market-based industry, where generators and electricity retailers will be free to contract with each other for supply of electricity. This employed the vesting contract envisaged to be a measure to enable transition to a competitive wholesale market. The Long Run Marginal Cost (LRMC) method which involves calculating the full life cycle cost of the lowest-efficient-cost new entrant generator was used. This was applied in two ways via:

1) benchmark costing: this creates a proxy for the market price which an efficient generator is expected to operate below and

2) individual LRMC for each generator: this sets prices for each generator according to its plant and site specific costs.

The individual (site-specific) LRMC model requires each new entrant Independent Power Producer (IPP) to apply to the NERC for approval beyond the MYTO benchmark.

The benchmark generation cost of an OCGT power plant is price required over the plant life to cover all the cost components as follows: capital cost, fuel cost, tax, transmission costs, return on capital, operating and maintenance cost both fixed and variable (with appropriate costs components escalated). These together with other factors to include capacitor factor, thermal efficiency (heat rate), plant internal energy use (auxiliary requirement) and availability form the input parameters for the LRMC financial model. The unit CoE generated is fined by calculating a price that makes the net present value of the power station equal to zero. The list of assumptions for building the LRMC financial model is depicted in Table 1 [19]. The model capital cost is calculated as weighted average cost of capital (WACC), from Equations (1)-(3), using capital asset pricing model (CAPM). This is proposed to provide a return on existing assets and appropriate incentives for future investment. 
Table 1. Assumptions for calculation of the WACC and LRMC for benchmark OCTG power plant generation tariff order [19].

\begin{tabular}{|c|c|c|c|c|}
\hline \multirow[b]{2}{*}{ Parameters } & \multicolumn{2}{|c|}{ MYTO 1} & \multicolumn{2}{|c|}{ MYTO 2} \\
\hline & $\begin{array}{c}\text { New } \\
\text { Entrant }\end{array}$ & $\begin{array}{c}\text { Successor } \\
\text { Gencos }\end{array}$ & $\begin{array}{c}\text { New } \\
\text { Entrant }\end{array}$ & $\begin{array}{c}\text { Successor } \\
\text { Gencos }\end{array}$ \\
\hline Installed Capacity, MW & - & - & - & - \\
\hline Capacity factor, $\%$ & 70 & 63 & 80 & 65 \\
\hline Marginal Loss Factor, \% & 8.05 & 8.05 & 8.05 & 8.05 \\
\hline Thermal efficiency, $\%$ & 34 & 34 & 32 & 32 \\
\hline Auxiliary requirement, \% & 1 & 1 & 2 & 2 \\
\hline Construction period, years & 2 & 2 & 3 & 3 \\
\hline Plant economic life, years & 20 & 20 & 20 & 20 \\
\hline Capital cost, US\$/kWh & - & - & - & - \\
\hline Fuel cost, US\$/mmBtu & 1.8 & 1.8 & 1.8 & 1.8 \\
\hline Fixed $\mathrm{O} \& \mathrm{M}$ cost, $\mathrm{N} / \mathrm{MW} /$ Year & - & - & - & - \\
\hline Variable $O$ \& $M$ cost, $N / M W h$ & - & - & - & - \\
\hline Availability, \% & 95 & 95 & 95 & 95 \\
\hline $\mathrm{O} \& \mathrm{M}$ costs escalation , \% & - & - & - & - \\
\hline Capital cost escalation, $\%$ & - & - & - & - \\
\hline Fuel cost escalation, $\%$ & - & - & - & - \\
\hline Corporate tax rate, $\%$ & 32 & 32 & 32 & 32 \\
\hline Gearing ratio (debt/equity) & $70: 30$ & $70: 30$ & $70: 30$ & $70: 30$ \\
\hline Risk-free rate , $\%$ & 18 & 18 & 18 & 18 \\
\hline Nominal cost of debt, \% & 24 & 24 & 24 & 24 \\
\hline Nominal return on equity , $\%$ & 29 & 29 & 29 & 29 \\
\hline Nominal before tax WACC, \% & 25 & 25 & 25 & 25 \\
\hline Nominal after tax WACC, \% & 17 & 17 & 17 & 17 \\
\hline Real pre-tax WACC, \% & 11 & 11 & 11 & 11 \\
\hline Real after tax WACC, \% & 7 & 7 & 7 & 7 \\
\hline
\end{tabular}

$$
\mathrm{WACC}=R_{d} \times \frac{D}{D+E}+R_{e} \times \frac{E}{D+E}
$$

In which $R_{e}$ is the nominal cost of equity; $D$ is the total market value of debt; $E$ is the total market value of equity and $R_{d}$ is the nominal cost of debt, given as:

$$
R_{d}=R_{f}+D R P+I C
$$

$D R P$ is the debt risk premium; $I C$ is the debt issuance cost lending in Nigeria; and $R_{f}$ is the risk free rate observed in the market. Equations (1) and (2) calculate weighted average cost of capital (WACC) without tax and return on equity respectively. 


$$
R_{e}=R_{f}+\beta e\left(R_{m}-R_{f}\right)
$$

$R_{e}$ is the return on equity; $\beta e$ is the correlation between the equity risk and overall market risk; $R_{m}$ is the return on the market portfolio; and $\left(R_{m}-R_{f}\right)$ is the market risk premium. The nominal post tax WACC and real pre tax WACC are calculated with Equations (4) and (5) respectively.

$$
\begin{aligned}
& \text { Nominal post tax } \operatorname{WACC}(w)=R_{e} \times \frac{E}{V}+R_{d} \times\left(1-T_{c}\right) \times \frac{D}{V} \\
& \text { Real pre tax } \operatorname{WACC}(\mathrm{RW})=\left[1+\left(w /\left(1-T_{c}\right)\right) /(1+i)\right]-1
\end{aligned}
$$

Here $V$ is the total market value of the business, i.e. debt plus equity; $T_{c}$ is the company tax rate; and $i$ is the inflation rate.

\section{Research Methodology}

As shown in Figure 1, the research employed thermodynamic modeling of OCGT power plant to augment technical data in MYTO model assumptions. The gas turbine engine for this study is a single shaft 202.6 MW (approximately $200 \mathrm{MWe}$ ) engine having thermal efficiency of $38 \%$ with design point data as shown in Table 2. The off design performance studies took into consideration the operating environment with ambient temperature values up to $45^{\circ} \mathrm{C}$ and a part-load operations down to 35\%-representing typical Nigerian operation scenario. Table 3 represents the technical characteristics of New Entrant Plants by NERC [19]. These data together with data from Table 1 was used with prescribed modifications to establish the base values for the probability distribution in the current study Table 4. Monetary figures of Table 3 were quoted in 2011

Table 2. Gas turbine engine design point parameter and performance data.

\begin{tabular}{cc}
\hline Design Point Parameter & Values \\
\hline Fuel heating value, LHV (MJ/kg) & 49.7365 \\
Ambient pressure (kPa) & 101.325 \\
Pressure ratio & 18.2 \\
Ambient temperature (K) & 288.15 \\
Turbine entry temperature, TET (K) & 1420 \\
Turbine speed [rpm] & 3000 \\
Mass flow (kg) & 650 \\
Ambient Relative humidity (\%) & 60 \\
Shaft power produced (MW) & 202.11 \\
Specific fuel consumption (kg/kWh) & 0.19 \\
Fuel flow $(\mathrm{kg} / \mathrm{s})$ & 10.76 \\
Exhaust gas temperature (K) & 754.68 \\
Exhaust gas $(\mathrm{kg} / \mathrm{s})$ & 653.03 \\
Thermal efficiency (\%) & 38.4 \\
\hline
\end{tabular}


Table 3. Technical Characteristics of New Entrant Plants-2012 [19].

\begin{tabular}{ccc}
\hline Description & Units & OCGT (New Entrant) \\
\hline Installed capacity & MW & 250 \\
Capital cost & US\$/kWh & 1200 \\
O \& M Cost (Fixed) & N/MW/Yr & $2,496,000$ \\
O \& M Cost ( Variable) & $\%$ & 920 \\
Capacity Factor & $\%$ & 80 \\
Auxiliary Requirement & Year & 2 \\
Economic life & Year & 20 \\
Construction period & $\%$ & 3 \\
Sent-out efficiency & $\%$ & 34 \\
Availability & $\$ / \mathrm{mmBtu}$ & 95 \\
Fuel costs & & 1.8 \\
\hline
\end{tabular}

Table 4. Baseline values and distribution types for variable input MYTO model parameters.

\begin{tabular}{cccc}
\hline Description & Units & OCGT (New Entrant) & Distribution Type \\
\hline Capital cost & US $\$$ KWh & 1033 & Triangular \\
O \& M Cost (Fixed) & N/MW/Yr & $2,496,000$ & Triangular \\
O \& M Cost ( Variable) & N/MWh & 920 & Triangular \\
Capacity Factor & $\%$ & 80 & Triangular \\
Sent-out efficiency & $\%$ & 34 & Triangular \\
Availability & $\%$ & 95 & Triangular \\
Fuel costs & $\$ / \mathrm{mmBtu}$ & 1.8 & Triangular \\
Capacity degradation & $\%$ & 1.0 & Triangular \\
Forex & $\$$ & 168 & Triangular \\
\hline
\end{tabular}

reference value and converted to 2016 value of money using Equation (6). Similarly, Equation (7) was used to convert $250 \mathrm{MW}$ plant capacity cost components of Table 3 to equivalent cost components capacity (200 MWe) in this study. As shown in Equation (7), the cost, $P_{E R}$ of a GT unit of size $S$ is related to cost, $P_{R_{0}}$ of the reference GT unit size $S_{o}$ by means of a scaling factor $f$ taken as 0.67 [20]. In Equation 6, $P_{R}$ is the price at reference year, $P_{O}$ is the original price. The ODP performance simulations data to include plant thermal efficiencies at varying load and ambient temperature among others were used to build the distributions for the power plant performance parameters in the MYTO model (Table 4) for MCS. Finally, the MCS of MYTO generation tariff order financial model in [21] was performed to determine the sensitivity of uncertain input parameters to OCGT power plant generation cost. 


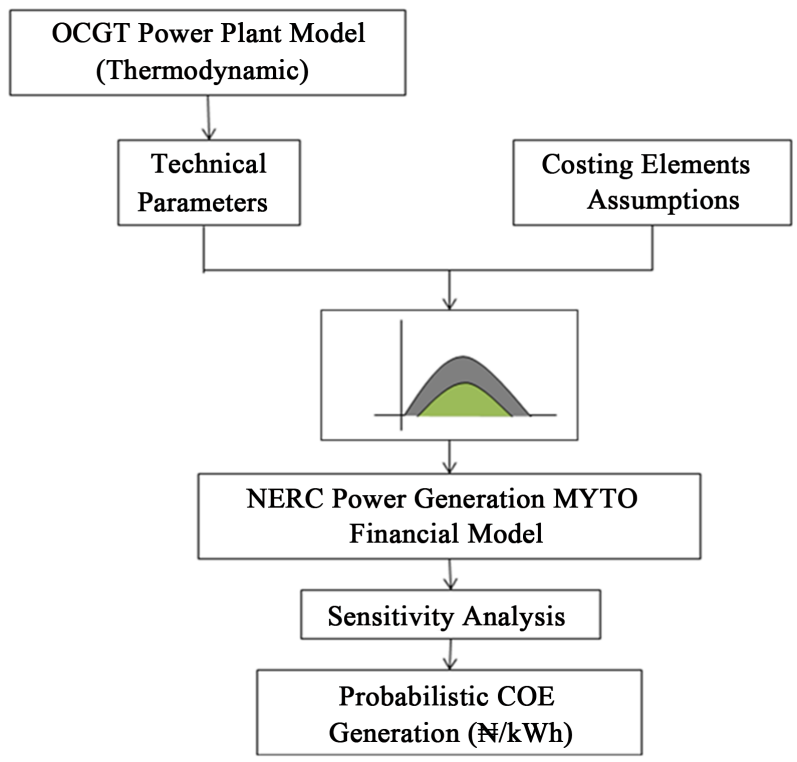

Figure 1. Layout of research approach.

$$
\begin{gathered}
P_{R}=P_{O} \times\left(\frac{\text { price index at reference year }}{\text { price index during the original price }}\right) \\
P_{E R}=P_{R_{o}} \times\left(S / S_{o}\right)^{f}
\end{gathered}
$$

\section{Results and Discussions}

The sensitivity of input parameters (both technical and economic) to OCGT generation cost in the MYTO generation financial model is presented. Table 5 shows statistics of probabilistic input data resulting from distribution types and nominal values of parameters. The generation $\mathrm{CoE}$ in $/ \mathrm{kWh}$ ranges from 9.89 to 15.45. The major contributors of uncertainty is outlined and ranked Figure 2 and Figure 3 respectively. Specifically in Figure 3, the value of the input parameters were ranked by effect on output mean of CoE (approximately 12.00 $\mathrm{N} / \mathrm{kWh}$ ). The most ranked input parameter is the foreign exchange rate (Forex). Quantitatively, this statistical value of Forex in MYTO has the ability of changing the mean CoE at $12.06 \mathrm{NWh}$ to a value between 10.68 and $13.27 \mathrm{kWh}$. The remaining input parameters in descending order of sensitivity are fuel cost; variable operation and maintenance $(\mathrm{O} \& \mathrm{M})$ cost; plant efficiency; average plant capacity degradation; fixed operation and maintenance cost; and plant capacity factor. However, effects of other input parameters namely: capital cost, deprecation, pre-tax real weighted average capital cost (WACC), and corporate tax rate were trivial, (at least on the assumption limits used for their distribution construction).

The three input parameters (thermal efficiency, fixed $\mathrm{O} \& \mathrm{M}$ cost, and plant capacity factor) (Figure 3), have negative correlation coefficients. Typically, this indicates that these parameters are each inversely proportional to the CoE when other input parameters are held constant. This reveals significant information. 
Table 5. Statistical data from various parameter distributions and COE distribution.

\begin{tabular}{ccccccccc}
\hline \multirow{2}{*}{ Parameter } & \multicolumn{9}{c}{ Statistics } \\
\cline { 2 - 8 } & Min. & Max. & Mean & Mode & Median & Std. Dev. & Skewness & Kurtosis \\
\hline Capital cost & 173,544 & 300,000 & 224,180 & 198,996 & $220,085.79$ & $27,305.24$ & 0.474 & 2.40 \\
O \& M cost (Fixed) & $72,741.5$ & $90,015.6$ & $78,499.5$ & $72,741.4$ & $77,800.96$ & 4071.56 & 0.57 & 2.40 \\
O \& M cost( Variable) & 1386.3 & 2386.3 & 1719.6 & 1386.3 & 1679.14 & 235.70 & 0.57 & 2.40 \\
Sent-out efficiency & $19.0 \%$ & $32.0 \%$ & $26.3 \%$ & $28 \%$ & $26.6 \%$ & $2.72 \%$ & -0.34 & 2.40 \\
Fuel costs (\$mmBtu) & 1.8 & 3.0 & 2.2 & 1.8 & 2.15 & 0.28 & 0.57 & 2.40 \\
Capacity factor & $35 \%$ & $80.0 \%$ & $65.0 \%$ & $80 \%$ & $66.8 \%$ & $10.61 \%$ & -0.57 & 2.40 \\
Capacity degradation & $1.0 \%$ & $3.0 \%$ & $1.7 \%$ & $1.0 \%$ & $1.6 \%$ & $0.47 \%$ & 0.57 & 2.40 \\
Forex & 161.0 & 420.0 & 300 & 320 & 304.5 & 53.32 & -0.22 & 2.40 \\
Depreciation & $5.0 \%$ & $8.0 \%$ & $6.0 \%$ & $5.0 \%$ & $5.9 \%$ & $0.71 \%$ & 0.57 & 2.40 \\
Pre-Tax Real WACC & $11.0 \%$ & $15.0 \%$ & $12.3 \%$ & $11.0 \%$ & $12.2 \%$ & $0.94 \%$ & 0.57 & 2.40 \\
Corporate tax rate & $32.0 \%$ & $40.0 \%$ & $34.7 \%$ & $32.0 \%$ & $34.3 \%$ & $1.89 \%$ & 0.57 & 2.40 \\
CoE (N/kWh) & 9.84 & 15.45 & 12.06 & 12.02 & 12.03 & 0.98 & 0.28 & 2.81 \\
\hline
\end{tabular}

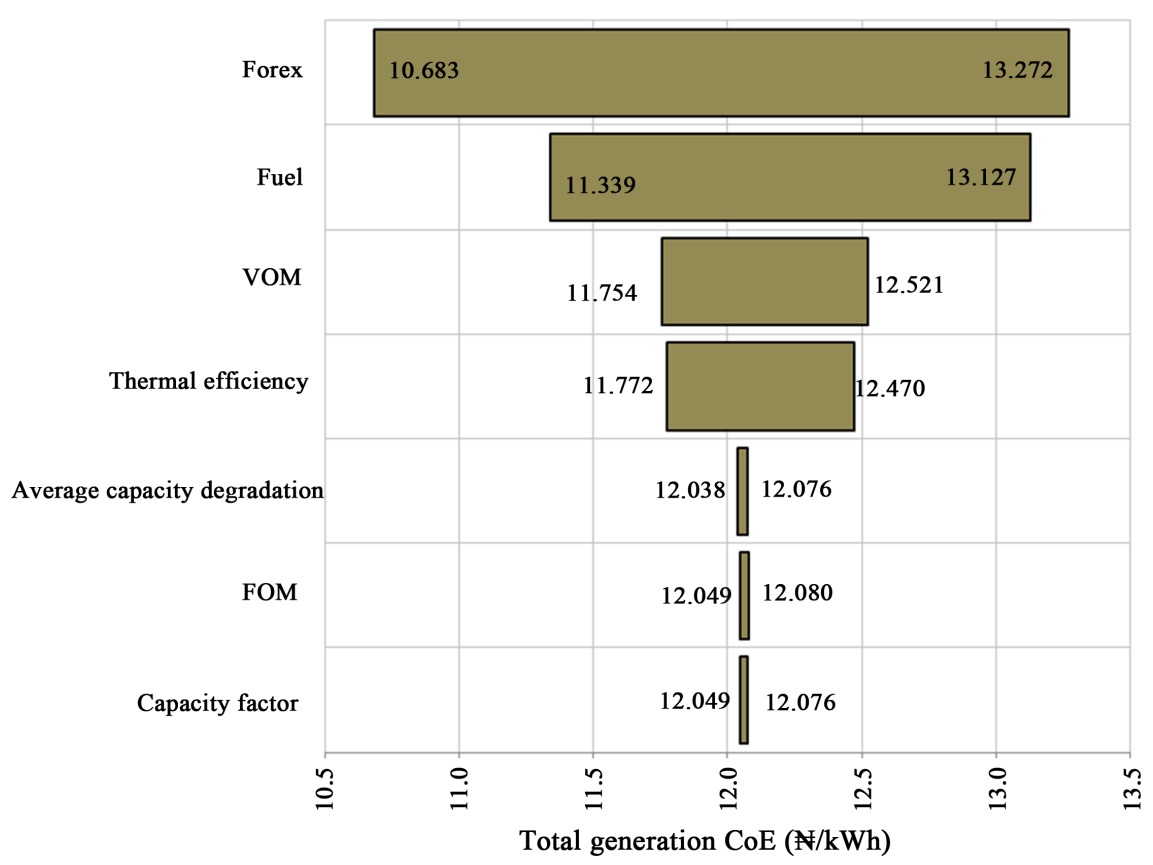

Figure 2. MYTO generation financial model input parameters ranked by effect on output mean of CoE, $(\mathrm{N} / \mathrm{kWh})$.

For instance, considering many factors that can affect thermal efficiency (partload operations, high ambient temperature, component degradations), it means is quite sensitive to the overall $\mathrm{CoE}$, since it will be almost impossible for it not to vary in the present power plant operations trend in Nigeria. Seemingly, power plant thermal efficient monitoring becomes essential for viable economic sustenance of given plant. To this end and given the present power plant operation 


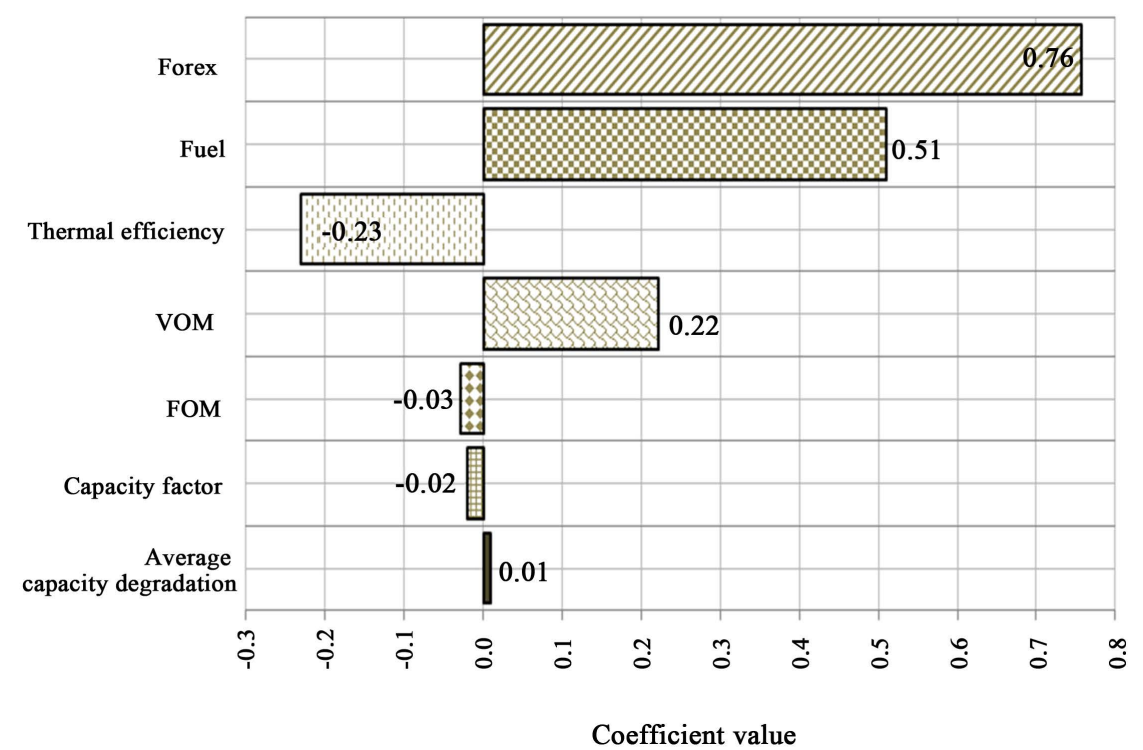

Figure 3. MYTO model for generation input parameter correlation coefficients.

with protracted part-load, it is recommendable for gas turbines engines with flexible efficiency in part-load operations like the GE LMS 100 among others be considered.

Invariably part-load operations will have multiple effects as it will directly affect both efficiency and capacity factor. Impact of plant degradation is further emphasized by the average capacity degradation correlation coefficient. This highlights the important of gas turbine engine's inlet air filtration application to limit fouling.

The probabilistic representation of $\mathrm{CoE}$ is useful in making decisions as it gives information on the probability of energy cost within the cost range in the probability distribution function. In Figure 4, starting with the two vertical lines corresponding to 10.5 and $13.80 \mathrm{~N} / \mathrm{kWh} \mathrm{CoE}$, numerous amount of information can be revealed. Normally, moving any of the vertical lines in either direction of increasing or decreasing (right or left) CoE gives the probability at any desired value. For instance, the state of the plot presently gives the following information: 1) the probability of CoE less than $10.50 \mathrm{~N} / \mathrm{kWh}$ is $5 \%$ and $95 \%$ above this value; 2) the probability of $\mathrm{CoE}$ between 10.5 and $13.80 \mathrm{~N} / \mathrm{kWh}$ is $90 \%$; 3 ) the probability of CoE below and above $13.8 \mathrm{~N} / \mathrm{kWh}$ is $5 \%$ and $5 \%$ respectively. Figure 5 reveals that certain input parameters will only have influence on the $\mathrm{CoE}$ at certain values (at least above 13.27 $\mathrm{NWh}$ for capacity factor, fixed and variable $\mathrm{O} \& \mathrm{M}$ costs). Typically the highly influential parameters will have impact at all level of CoE.

\section{Conclusion}

In this study, the probabilistic approach has been applied to study and discuss the sensitivity of selected input parameters to CoE generation in the MYTO generation tariff order financial model of NERC. The combined effect of protracted 


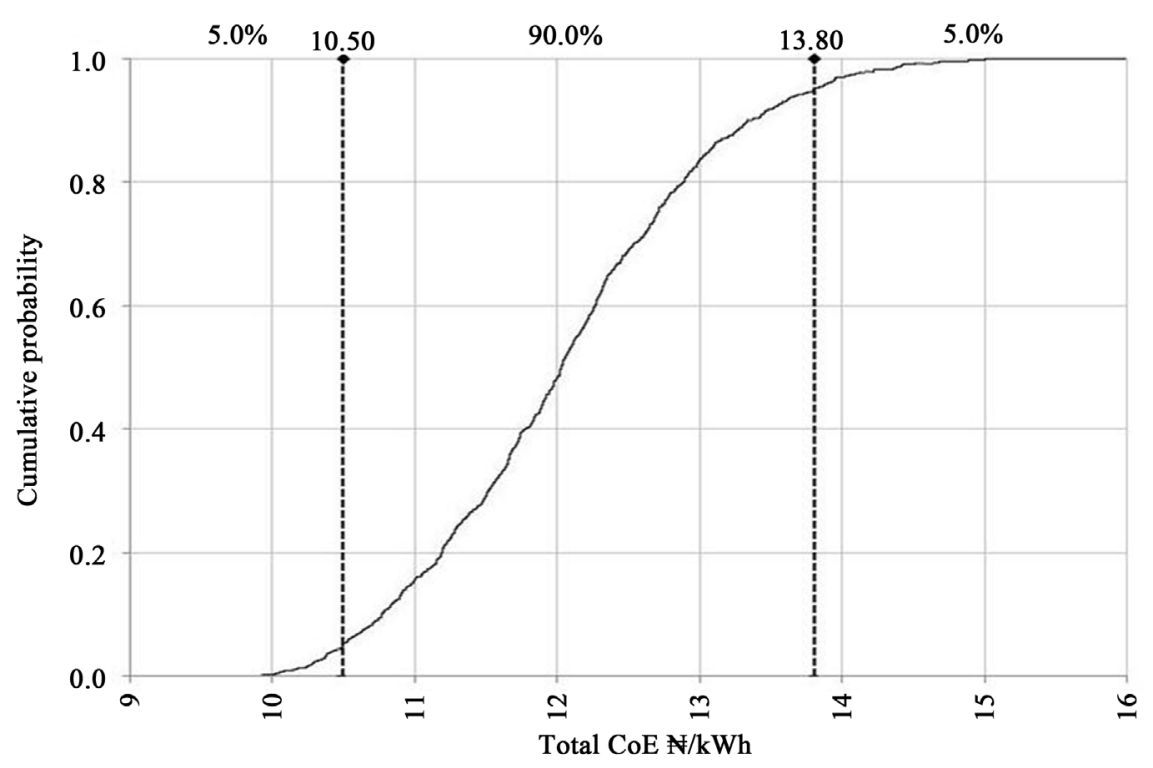

Figure 4. Total generation CoE with probability in percentile.

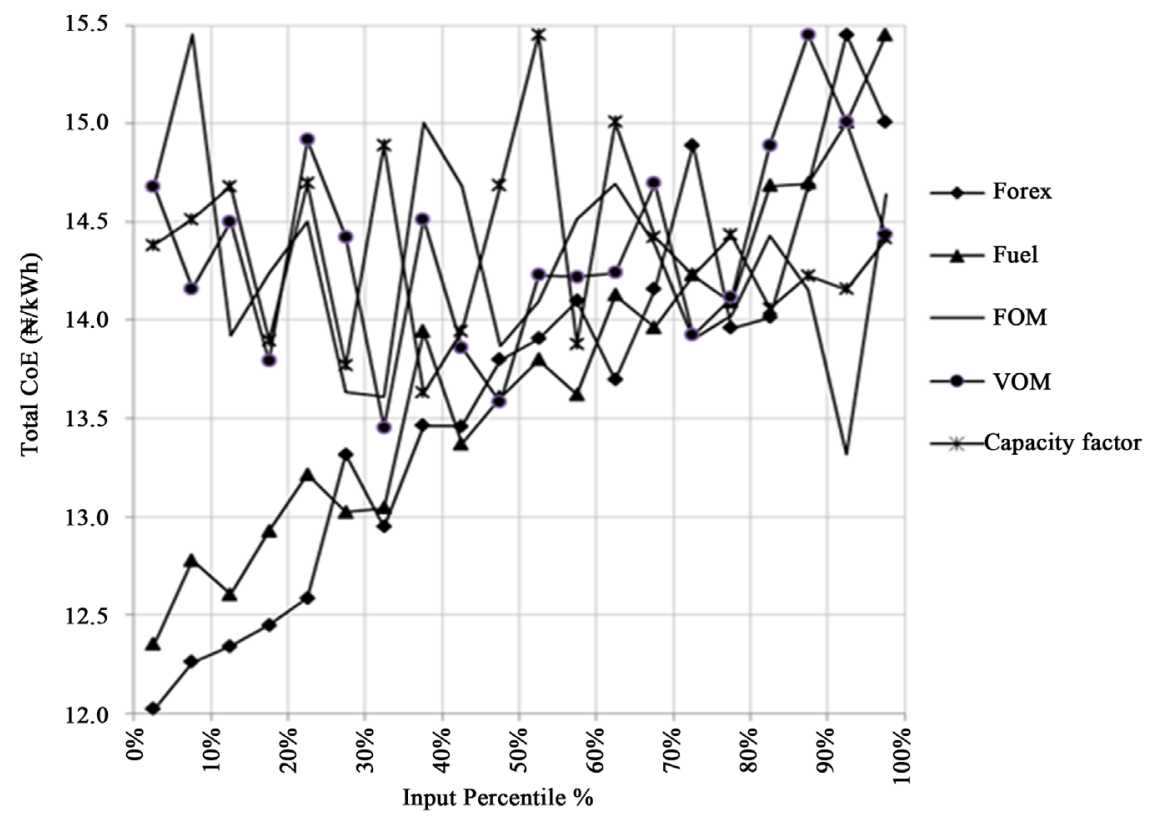

Figure 5. Change in output $100 \%$ percentile across range of input values.

part-load operation and increasing ambient temperature on the thermal efficiency of gas turbine engine was evaluated. The importance of gas turbine engines with flexible efficiency in part-load operations has been highlighted. Some selected input parameters prone to uncertainties in MYTO generation tariff order model were evaluated. The major input parameters with high uncertainty were revealed and their correlation coefficients determined. The probabilistic approach gives a better understanding of the CoE variations and to what extent it will go beyond a given expected value. The statistics of $\mathrm{CoE}$ in $\mathrm{kWh}$ is given as: minimum cost, 9.84; maximum cost, 15.45; mean cost, 12.06; mode, 12.02; 
median, 12.03; and standard deviation, 0.98 with cost distribution skewness and kurtosis of 0.28 and 2.81 respectively. To some extent, these results hinge on the assumption of this analysis, above all on the probabilistic distribution chosen for the MYTO model input parameters considered. This study will help investors and policy makers to take into account these variables in future development of MYTO pricing model and in achieving optimized and realistic model.

\section{References}

[1] Consultation Paper for the Review of the Transmission Company of Nigeria (TCN) Tariff under the Multi-Year Tariff Order Methodology; February 2015.

[2] Oyedepo, S.O., Fagbenle, R.O., Adefila, S.S. and Adavbiele, S.A. (2014) Performance Evaluation and Economic Analysis of a Gas Turbine Power Plant in Nigeria. Energy Conversion and Management, 79, 431-440. https://doi.org/10.1016/j.enconman.2013.12.034

[3] Sule, B.F., Ajao, K.R., Ajimotokan, H.A. and Garba, M.K. (2011) Compact Fluorescent Lamps and Electricity Consumption Trends in Residential Buildings in Ilorin, Nigeria. International Journal of Energy Sector Manage, 5, 162-168. https://doi.org/10.1108/17506221111145968

[4] Imperatives, Strategic. (2016) Report of the World Commission on Environment and Development: Our Common Future. http://www.un-documents.net/our-common-future.pdf

[5] Amadi, S. (2014) NERC's Strategic Sectorial Prioritization Action Plan for Post Privation Overall Development 2014. Nigerian Electricity Regulatory Commission. http://www.nercng.org/index.php/component/remository/NERC-Letters-Presentati ons-Reports-and-Papers/orderby,1/page, $2 /$ ? Itemid=0

[6] Iwayemi, A. (2008) Investment in Electricity Generation and Transmission in Nigeria: Issues and Options. International Association for Energy Economics, First Quarters, 37-42.

[7] Ekpo, E.O. (2012) MYTO 2 and Embedded Generation; GE Nigeria Power Development Summit 4/2012.

[8] Ransome, O. (2007) Nigerian Electricity Regulatory Commission's-Notice of Proposed Establishment of a Methodology for a Multi-Year Tariff Order; Federal Republic of Nigeria Official Gazette. The Federal Government Printer, Lagos, 18, 124-133

[9] Walter S., Danie, J.P. and Thomas, H. (1995) A Manual for the Economic Evaluation of Energy Efficiency and Renewable Energy Technologies (NREL) Report No. NREL/TP-462-5173.

[10] The Economic Appraisal of Investment Projects at the European Investment Bank (EIB), 2013.

http://www.eib.org/attachments/thematic/economic_appraisal_of_investment_proj ects_en.pdf

[11] Anosike, N.B. (2013) Technoeconomic Evaluation of Flared Natural Gas Reduction and Energy Recovery Using Gas-to-Wire Scheme. Ph.D. Thesis, Cranfield University, United Kingdom.

[12] Swan, L.G. and Ugursal, V.I. (2009) Modeling of End-Use Energy Consumption in the Residential Sector: A Review of Modeling Techniques. Renewable and Sustainable Energy Reviews, 13, 1819-1835. https://doi.org/10.1016/j.rser.2008.09.033

[13] Alfares, H.K. and Nazeeruddin, M. (2002) Electric Load Forecasting: Literature Survey and Classification of Methods. International Journal of Systems Science, 33, 
23-34. https://doi.org/10.1080/00207720110067421

[14] Tzafestas, S. and Tzafestas, E. (2001) Computational Intelligence Techniques for Short Term Electric Load Forecasting. Journal of Intelligent and Robotic Systems, 31, 7-68. https://doi.org/10.1023/A:1012402930055

[15] Nowicka-Zagrajek, J. and Weron, R. (2002) Modeling Electricity Loads in California: ARMA Models with Hyperbolic Noise. Signal Processing, 82, 1903-1915. https://doi.org/10.1016/S0165-1684(02)00318-3

[16] Paatero, J.V. and Lund, P.D. (2006) A Model for Generating Household Electricity Load Profiles. International Journal of Energy Research, 30, 273-290. https://doi.org/10.1002/er.1136

[17] Larsen, B.M. and Nesbakken, R. (2004) Household Electricity End-use Consumption: Results from Econometric and Engineering Models. Energy Economics, 26, 179-200. https://doi.org/10.1016/j.eneco.2004.02.001

[18] NERC Multi-Year Tariff Order for the Determination of the Cost of Electricity Generation for the period 1 June 2012 to 31 may 2017.

http://www.ecowrex.org/system/files/documents/2012_multiyear-tariff-order-gener ation_nerc.pdf

[19] Amadi, S. and Andzenge, S. (2012) Multi-Year Tariff Order for the Determining of the Cost of Electricity Generation for the Period 1 June 2012 to 31 May 2017; Nigerian Electricity Regulatory Commission. http://www.nercng.org

[20] Browne, T. (2007) Engineering Economics and Economic Design for Process Engineers. CRC Press, Bosca Raton.

[21] MYTO-New-Entant-IPP.xlsm Model. http://www.nerc.ng

\section{Submit or recommend next manuscript to SCIRP and we will provide best service for you:}

Accepting pre-submission inquiries through Email, Facebook, LinkedIn, Twitter, etc. A wide selection of journals (inclusive of 9 subjects, more than 200 journals)

Providing 24-hour high-quality service

User-friendly online submission system

Fair and swift peer-review system

Efficient typesetting and proofreading procedure

Display of the result of downloads and visits, as well as the number of cited articles

Maximum dissemination of your research work

Submit your manuscript at: http://papersubmission.scirp.org/

Or contact epe@scirp.org 